This item was submitted to Loughborough's Research Repository by the author.

Items in Figshare are protected by copyright, with all rights reserved, unless otherwise indicated.

\title{
Volunteer mentors as informal educators in a youth physical activity program
}

PLEASE CITE THE PUBLISHED VERSION

http://dx.doi.org/10.1080/13611261003678887

\section{PUBLISHER}

(c) Taylor and Francis

\section{VERSION}

AM (Accepted Manuscript)

\section{PUBLISHER STATEMENT}

This work is made available according to the conditions of the Creative Commons Attribution-NonCommercialNoDerivatives 4.0 International (CC BY-NC-ND 4.0) licence. Full details of this licence are available at: https://creativecommons.org/licenses/by-nc-nd/4.0/

\section{LICENCE}

CC BY-NC-ND 4.0

\section{REPOSITORY RECORD}

Sandford, Rachel A., Kathleen Armour, and Deborah J. Stanton. 2019. "Volunteer Mentors as Informal Educators in a Youth Physical Activity Program". figshare. https://hdl.handle.net/2134/19793. 


\title{
Volunteer mentors as informal educators in a youth physical activity programme
}

\author{
Rachel A. Sandford ${ }^{1}$, Kathleen M. Armour ${ }^{2}$ \& Deborah, J. Stanton ${ }^{3}$ \\ ${ }^{1}$ Institute of Youth Sport, School of Sport, Exercise \& Health Sciences, Loughborough University, \\ Leicestershire, LE11 3TU, UK. R.A.Sandford@lboro.ac.uk \\ ${ }^{2}$ School of Sport, Exercise \& Health Sciences, Loughborough University, Leicestershire, LE11 3TU, \\ UK. K.M.Armour@lboro.ac.uk \\ ${ }^{3}$ West Kent College, Brook Street, Tonbridge, Kent, TN9 2PW, UK. deborahstanton@wkc.ac.uk
}

\begin{abstract}
This paper reports data from a four-year longitudinal evaluation of a UK project, which used outdoor activities as a vehicle for enhancing the personal and social development of disaffected youth. In particular, it examines the role played within this project by volunteer learning mentors. Following a summary of relevant literature and an overview of the project design and evaluation strategy, data are reported on the impact and effectiveness of these mentors. The findings suggest that there is much potential for mentors to function as informal educators in youth programmes such as the one outlined here. However, a lack of preparation and the considerable challenges faced in establishing and maintaining mentoring relationships with young people in schools can restrict their impact. It is argued that similar future initiatives would benefit from greater pre-planning and an improved understanding of how mentors and other youth professionals can work with and alongside each other.
\end{abstract}

\section{Introduction}

This paper reports data from a four-year longitudinal evaluation of a corporate-sponsored project in the UK, which used outdoor and adventure physical activity as a vehicle for enhancing young people’s personal and social development. There has been a proliferation of such programmes in recent years within the UK and beyond, and this can be viewed, in part, as a response to mounting public concern over a perceived increase in youth disaffection, anti-social behaviour and social disengagement throughout the Western world (Smink, 2000; Davies, 2005; Sandford, Armour \& Warmington, 2006). Youth disaffection is a complex and multi-dimensional phenomenon influenced by numerous factors and encompassing a wide range of behaviours, attitudes and experiences (Steer, 2000; Sandford et al., 2008a). It can be expressed in various ways including through disruptive or antisocial behaviour, a rejection of 
civic responsibilities or disengagement from educational services/activities. Indeed, youth disaffection within schools, characterised by truancy, exclusions and disruptive behaviour (active disaffection) or alienation, non-participation and underachievement (passive disaffection), is currently viewed as a particular cause for concern, certainly within the UK (DfES, 2005; It is this particular form of youth disaffection that is the focus of the research presented here.

Remedial programmes for so-called disaffected youth tend to have broad aims that are focussed around reducing deviant behaviour, raising aspirations, and promoting pro-social development (Merton \& Parrott, 1999; Colley, 2003a,b; Webb \& Vulliamy, 2004). Central to this framework is the enduring belief that participation in physical activity programmes can yield substantial benefits for disaffected, disengaged or disadvantaged young people (Miller, Bredemeier \& Shields, 1997; Fraser-Thomas, Côtè \& Deakin, 2005; Bailey, 2008). There is a strong theoretical foundation underpinning the field, largely emanating from a number of key authors in the US and grounded in issues such as teaching life skills, developing resiliency, and facilitating a growth in perceived personal and social responsibility (e.g. Burt, 1998; Lawson, 1999; Hellison, 1995). In addition, recent research focused on physical activity as a means of promoting positive youth development has contributed much to this debate (e.g. Holt, 2008). Certainly, Martinek and Hellison (1997) argue, for example, that:

The nature of physical activity - active, interactive, highly emotional - certainly provides the possibility of exploring and practising values, teamwork, goalsetting, peer-teaching, conflict resolution, and so on (p.44).

Moreover, the school context (more specifically, physical education and school sport) has come to be perceived as an apposite setting in which to run physical activity programmes and promote young people’s socio-moral development (Larson \& Silverman, 2005; Parker \& Stiehl, 2005); a belief that is reflected in a number of recent government policies in both the UK and beyond (see Bailey, 2008; Sandford, Duncombe \& Armour, 2008). 
The “social problems industry” (Pitter \& Andrews, 1997 p.85) driven by such sentiments, is also believed to be responsible for the recent generation of a number of privately sponsored initiatives. These programmes, such as the project outlined in this research have, as their fundamental aim, the (re)engagement and positive development of disaffected or disadvantaged youth. Key elements of such programmes, it is argued, are the social processes that occur within the physical activity context, and the relationships that can be developed between the young participants and adult leaders (Crabbe, 2006; Petitpas, Cornelius \& Van Raalte, 2008) including, for example, teachers, youth coaches and mentors. However, although aspirations for these physical activity programmes are high, empirical evidence to support their efficacy is comparatively sparse (Long \& Sanderson, 2001; Crabbe, 2006; Bailey et al., 2009). As such, many authors have noted that there remains a need for more longitudinal and systematic evaluation research that can build on the theoretical foundations and provide evidence regarding the mechanisms by which positive outcomes for young people are achieved and sustained (Sandford et al., 2006; Bailey et al., 2009). The evaluation work outlined in this paper represents one example of such research.

The physical activity project evaluated in this research, the HSBC/Outward Bound project, was fully funded by a corporate sponsor and was targeted at disengaged / disaffected young people within schools. Moreover, the sponsors (HSBC) ${ }^{1}$ also funded the independent evaluation of the initiative (to run for the entire life of the project) and actively supported the dissemination of findings within relevant academic communities. Most notably, however, the project design, which was developed by the funders in collaboration with the project deliverer, Outward Bound ${ }^{2}$, was somewhat unique in that it attempted to combine three complementary learning strategies recommended in the research literature on re-engaging young people, namely: locating the learning in physical activity contexts; using the physical activity setting as an opportunity for delivering informal education outcomes and; involving 
adult volunteers as learning mentors for the young people. It is the latter two of these strategies that form the core focus of this paper i.e. the role and impact of the adult mentors. In order to provide some context for the discussion that follows, therefore, the paper begins with a summary of relevant literature relating to the concepts of mentoring and informal education. This is followed by an overview of the structure of the HSBC/Outward Bound (HSBC/OB) project and the evaluation research strategy employed. Data are reported on the role, impact and effectiveness of the adult mentors in this research, and the discussion concludes with a consideration of the implications of the findings for future similar programmes.

\section{An overview of relevant mentoring and informal education literature}

Youth mentoring has undergone a "spectacular expansion” (Colley, 2003a, p.1) in a variety of professional organisations and disciplines in recent times, including within the field of education (Garvey \& Alred, 2000). There has also been a proliferation in the literature on mentoring, with authors highlighting a drive to encourage adults to take up mentoring roles with young people in a number of countries including North America, the UK, and Australia (Reid, 2002; Colley, 2003a; Philip et al., 2004; DuBois \& Karcher, 2005). Tackling youth disaffection and social exclusion is a key target for many mentoring initiatives (Shiner, Newburn, Young \& Groben, 2004) based on research which suggests that a learning relationship with an adult other than a parent (or teacher) can lead to positive outcomes for disaffected young people (Bennetts, 2003) and that these connections can "powerfully influence the course and quality of adolescents’ lives” (Rhodes, 2001 p.1). Reid (2002) sums up the suggested benefits of youth mentoring as follows:

Studies have shown that young people who have a significant adult or 'mentor' in their life, other than family members, are more likely to achieve in a variety of ways, including socially and academically (p. 154). 
The goals of these 'engagement mentoring' programmes (Colley, 2003b) have been identified as including increasing academic success, lowering deviant behaviour, increasing self-esteem and improving employability (e.g. Philip, 2003). However, the benefits are not just 'one-way' as there are potential gains for the adult mentors too (e.g. Roberts, 2000; Philip \& Hendry, 2000). In particular, researchers have suggested that mentoring can allow mentors to acquire new interpersonal skills (Garvey \& Alred, 2000) and aid positive intergenerational relationships (Rhodes, 2004). The relationship aspect of mentoring remains key, and studies of disaffected or 'at-risk' youth have shown that helping relationships with nonparental or non-professional adults can function as a means of protection and contribute to the development of resiliency (Werner, 1995). There are links here to the physical activity literature, as noted above, and such research helps to reinforce the assertion that it is the social processes experienced and not the activity undertaken per se that results in positive outcomes for young people (Sandford et al., 2006). The concept of mentoring is by no means novel, therefore, but modern mentoring schemes do represent something of a new breed, not generally characterised by the spontaneity and informality of more traditional mentoring relationships. Moreover, there appears to be a greater focus on the educational role played by mentors within structured mentoring schemes, and the direct contribution that mentors can make to young people's positive (and socially desirable) development (Bennetts, 2003; Colley, 2003a). Certainly, within the HSBC/Outward Bound programme, there was a clear assumption that the mentors would actively facilitate and enhance the learning experience for the young people. Indeed, there was a clearly stated intention that they would adopt an informal educator role.

The concept of informal education (IE) has gained significant currency in recent years (McGivney, 1999; Colley, Hodkinson \& Malcolm, 2002) and is associated with a growing recognition that learning is a fluid, adaptable and collaborative process (Jeffs, 2001). 
Recently, this recognition has influenced government education policies in the UK; for example the introduction of Extended Schools ${ }^{4}$, Learning Mentors in some inner city schools ${ }^{5}$ and the Education Outside the Classroom Manifesto (House of Commons: Education and Skills Committee, 2005). These examples are evidence of the growing interest by education policy makers in related areas such as youth mentoring (Colley, 2003a), situated learning (Lave \& Wenger, 1991), and experiential learning (Jarvis, 1994). In addition, IE practice also draws on popular educational theories relating to reflection (Dewey, 1933; Schön, 1983; Boud, 1985), conversation and dialogue (Freire, 1972; Burbules, 1993; Jeffs \& Smith, 1999), and pays particular attention to education as a process rather than a product (Bruner, 1960).

There is a broad understanding that informal educators work in a wide range of professions and educational contexts, making use of everyday situations to create environments where learning is drawn out from participants' own experiences and beliefs (Doyle 2001). However, beyond that there appears to be some difficulty in agreeing upon a working definition of the term 'informal education'. In one of the earliest texts to make reference to IE, John Dewey claimed that its purpose was to create environments that stimulate and direct learning: "In what we have termed informal education, subject matter is carried directly in the matrix of social intercourse” (1961, p. 181). Similarly, Brew (1946) defined informal education as entailing "active participation in a variety of social units" (p.22) while, more recently, Rogers (2004) characterised it as being highly contextualised and highly participatory.

Colley et al., (2002) explored the discourses around both non-formal and informal learning and concluded that the terms are often used inter-changeably without clarification of their meaning, and that much of the literature defines them by what they are not - i.e. formal - rather that what they are. This leads to a tendency to compare IE with formal education or schooling (Doyle 2001), thus implying that informality is a rather loose approach to learning. 
However, Colley et al., (2002) argued that it is often impossible to make a clear distinction between informal learning and IE or, indeed, between formal and informal learning/education, as elements of both are present in most learning and educational exchanges. It is important to note, however, that for informal educators, practice is carried out with intent; thus IE is purposeful. Moreover, individual learners are viewed as being active in the learning process rather than passive recipients of information transmitted by 'the educator'; thus the co-participatory nature of the IE process is foundational.

As noted earlier, a novel feature of the HSBC/OB project was that it attempted to combine a number of related learning strategies. Not only did it include the use of mentors, therefore, but it also had an explicit focus on informal education and sought to employ both strategies within physical activity contexts both in and beyond schools. It is clear from the above discussion that there are, indeed, many areas of overlap between the fields of mentoring and informal education e.g. the importance of social relationships, learning as a collaborative process and facilitating personal development within and beyond formal settings. Such shared common ground would appear to underline the potential for these fields to usefully inform, complement and strengthen each other. Moreover, there are perceptible links here with the physical activity/education literature. Of particular significance, is the realisation that the personal and social skills that physical education/sport has long claimed to develop in young people resonate strongly with the learning outcomes claimed for IE and, to some extent, modern mentoring schemes; for example, life skills (Danish, 2002), teambuilding skills (Holt \& Sehn, 2008), inter-personal skills (Theokas, Danish, Hodge, Heke \& Forneris, 2008), and improved educational achievement (Long et al., 2002). What was interesting for this research, therefore, was to see how these various 'worlds' collided in one project. 


\section{Overview of the HSBC/Outward Bound project}

The HSBC/Outward Bound project, which ran from September 2003 to August 2008², sought explicitly to work in partnership with schools to promote the personal, social and educational development of disaffected or disengaged young people through the medium of physical activity. A partnership between HSBC in the Community (see endnotes) and the Outward Bound Trust, the project offered a year-long programme of residential outdoor/adventurous activity experiences for five successive cohorts of pupils (aged 13-14 years) from five schools in the deprived Docklands area of London. Although pupil selection was left to the discretion of teachers, and based primarily on the premise that individuals would 'benefit' in some way from project involvement, the intention was that the HSBC/OB project would target, in particular, those young people who were actively disruptive within lessons as well as those who distanced themselves from educational processes (e.g. through frequent truancy) or who were withdrawn or isolated within school. This research, therefore, can be seen to adopt a broad and inclusive understanding of the concept of youth disaffection.

The physical activity programme undertaken by the young people in the HSBC/OB project was designed by the staff at Outward Bound and was intended to closely reflect its core aims as an organisation (Outward Bound, 2009). Indeed, one Outward Bound manager, interviewed at the beginning of the evaluation research, was keen to point out that "a philosophy of education” lay at the heart of Outward Bound's work and underpinned the collaborative project with HSBC (Armour \& Sandford, 2004 p.83). As such, there were both physical and educational elements to each of the activities involved in the HSBC/OB project, and there was a strong focus on the potential for personal development. The activities undertaken included, for example, rock climbing, kayaking, raft-building, gorge walking, high ropes courses, and various group problem solving tasks. Each young person also undertook a group expedition, which included a walk of several miles in rough terrain and at 
least one overnight camp during which individuals were responsible for cooking their own food. In combination, these activities were perceived to provide participants with both individual and group challenges and to develop skills relating to team building, communication, empathy and responsibility. Moreover, each activity session ended with a short review period, in which pupils were asked to identify what they had learnt through participating in the activity and encouraged to consider how they might be able to apply this learning to other situations and contexts.

It is worth emphasising that London Docklands is an area of stark social and economic contrasts, where a highly prestigious business development (the location of HSBC's UK head office) towers uneasily over a locality characterised by extreme social deprivation (the location of the project schools). Indeed, involvement in the HSBC/OB project was described by the corporate sponsor as fundamentally “a philanthropic exercise”. Hence, HSBC's aims for the programmes included: making a contribution to (local) community development; enhancing the personal, social and academic development of the young people (during and beyond both projects); fostering positive relationships between the five partner schools; and offering HSBC staff opportunities to engage in community activities. In relation to this latter point, a central element of the project was the involvement of a number of HSBC staff as volunteer mentors. Interestingly, these mentors were intended (in theory, at least) to play an integral role in facilitating both the positive impact of project involvement on the young participants and the development of positive community relations through established contact with the project schools. Each year, between 10 and 15 individuals from throughout HSBC's workforce were selected, following an application process, to act as mentors for the young people involved in the project. In order to help them prepare for their role, they were given brief training led by youth workers from one of the project schools. The training covered issues such as youth culture, child protection, and 
managing challenging behaviour, as well as introductory information on informal education as a learning strategy and practical advice on building and maintaining relationships with young people. The nature of this training evolved throughout the life of the project (influenced, in part, by mentor feedback) from a single weekend session in year 1 to a oneday course followed by regular update sessions by year 4 . The expectation was that, having undergone this training, the mentors would work with teachers and pupils both within the project activity sessions and (in theory) in follow-up activities within the schools and local community. More specifically, it was intended that each mentor would work with a specific group of young people in the outdoor activity setting, not in an instructional role (this was undertaken by Outward Bound Instructors) but by providing support, giving encouragement and reinforcing learning points. In addition, it was hoped that mentors would maintain contact with an allocated project school outside of activity sessions, and collaborate with other mentors and teachers to identify / develop additional activity opportunities for pupils. However, as will now be shown, these intentions regarding the mentor role, although strong in theory, proved more challenging in practice.

\section{Theoretical Framework for the Evaluation Research}

The discussion so far has examined the core learning strategies that underpinned the HSBC/OB project and has provided an overview of the structure and objectives of the initiative. We now briefly outline how these factors influenced the design of the evaluation research. The complexity of the project, in particular the composite and dynamic contexts in which it was located and the broad scope of its aims, resulted in some significant challenges for the researchers. The first challenge was to design a credible evaluation strategy that would allow project impact to be ascertained and the first step was to attempt to clarify the theories 
of change underpinning the project design (Weiss, 1995). As Connell \& Kubisch (1998) point out, such clarification is essential for the evaluation process because:

Plausible theories of change will no doubt be complex and pluralistic, but if they are to be implemented (doable) they cannot be contradictory, and if they are to be evaluated (testable) they cannot be unarticulated (p. 31).

The next step was to build a basic project Logic Model (Kellogg Foundation, 2001) to try to ensure a) that researchers and all participants had a clear understanding of project activities and intended outcomes, and the assumptions underpinning them; and b) that the best attempt possible was made to ensure that impact upon pupils could be attributed (even if only partially) to the project rather than to other, overlapping and concurrent projects and initiatives located in pupils' schools or communities (Fig. 1). It was certainly important to establish with the funders at the outset that providing unambiguous 'proof' of the impact of this particular project on individual pupils would be difficult (Granger, 1998; Crabbe, 2006). As Guskey (2005-6) comments, such proof would require "a level of experimental rigor that is hard and often impossible to attain in practical school settings” (p. 13). Nonetheless, a research design was established that would provide evidence of impact that could, in part at least, be attributed to young people's involvement in the project.

As more data were collected, a detailed Theory of Change Logic Model (Kellogg Foundation, 2001) was created which focussed on the indicators of change and helped to inform thinking about the evaluation framework required. Ideally, such models would be developed at the project design stage although, in practice, evaluators are often commissioned after the design work has been completed and a programme is in place (DfEE, 2000). In this research, the evaluators were commissioned just as the project was entering its first annual cycle so basic Logic Models were created from (limited) available documentation and early interviews with the project sponsors and partners. In relation to this analysis of mentor involvement in the project, it is interesting (and important given later findings regarding 
mentor role ambiguity) to note that even at this early stage of the research, the Basic Logic Model highlighted a lack of clarity in the ways in which project aspirations for mentoring would be realised in practice (see figure 1).

\section{Methods and Data Sources}

In total the HSBC/Outward Bound project was evaluated over 4 years, and data were collected on 588 pupils, 7 teachers and 51 mentors. The evaluators utilised a wide range of predominantly qualitative research methods to gather data on the impact of the HSBC/OB project on all project participants. In summary, data were collected from participant observation (of outdoor activity sessions) and researcher fieldnotes, semi-structured reflective journals (for both pupils and mentors), individual interviews (with teachers, mentors and programme funders/organisers), focus groups (with pupils and mentors), and structured feedback sheets (for pupils, teachers and mentors). In addition, and central to data collection on pupils, was the generation of individual participant profiles. This profiling process, in which each pupil's progress (as reported by school staff) was monitored at six monthly intervals, from a baseline level recorded at the outset, has been outlined elsewhere (e.g. Amour \& Sandford, 2008). Further detail is not presented in this paper because the main focus is on the adult mentors. Suffice to say, however, that the strategy was both dynamic, to reflect the flexibility schools were given in pupil selection for the project, and multi-layered, to try to capture all the relevant data on each pupil. The research design for the evaluation was created by drawing upon examples of good practice from relevant literature (e.g. Clark \& Moss, 2001; Oliver \& Lalik, 2001; Harper, 2002) and was informed by a body of research which highlights the value of utilising multiple research techniques in order to generate rich information (e.g., Patton, 2002; Punch, 2002; Bryman, 2006). 
Data on the mentors' perceptions and experiences of the project were generated through observations of structured activity sessions and informal conversations in these contexts, as well as from 19 individual interviews, 8 focus groups and 20 reflective journals. The core aim of these research methods was to explore individual mentor experiences of the project (including mentor selection and training), determine their thoughts about the mentoring process (e.g. what they felt they had brought to/gained from it, whether it had met their expectations and if/how they saw it developing) and discuss any key issues, problems or concerns that were felt to be significant to them. The raw data generated through this process, therefore, consisted of interview transcripts, journal entries and researcher fieldnotes.

Data analysis was undertaken using a grounded theory process similar to that described by Harry, Sturges \& Klingner (2005). Thus, data from these information sources were analysed systematically by coding in stages (Glaser \& Strauss, 1967; Strauss \& Corbin, 1998) until themes were generated and verified. However, following Charmaz's (2000) notion of constructivist grounded theory, the analysis process reflected a shift from the traditional, structured versions of grounded theory to a more "open-ended practice" that allowed for active coding and a greater focus on participants' thoughts, feelings and differing points of view. As Charmaz notes, this approach allows grounded theory methods to be used “as flexible, heuristic strategies rather than as formulaic procedures” (p.510).

Given the long-term nature of the project (4 years) the analysis of evaluation data was an ongoing process, in which emerging data helped to focus further data collection and shape subsequent coding. This was deemed to be particularly beneficial in this research, as the involvement of successive cohorts of mentors over the four year period meant that questions or issues raised early in the evaluation could be addressed through later changes to the data collection strategy. Moreover, constant comparison between the data from each project year helped to highlight themes / issues that were common to all mentors as well as those that 
were specific to each cohort. This process helped to facilitate a process of thematic saturation and the identification of disconfirming cases. An illustrative example of the data analysis process adopted in this research can be found in Figure 2.

The discussion now moves on to look at some of the key findings from the data that relate to the role and effectiveness of the adult mentors. It is worth noting at this point that all names shown in the following analysis are pseudonyms allocated by the evaluators. In addition to mentors' names, there is also a reference to which cohort or cohorts they were involved with because some mentors participated in more than one project year.

\section{Findings}

The data from the first four years of the HSBC/Outward Bound project provide support for the notion, as suggested in a growing body of literature (Colley, 2003a; DuBois \& Karcher, 2005), that there can be benefits for all participants in the youth mentoring process. For example, school staff indicated that they appreciated the role that mentors played in sharing their workload during activity sessions and, more particularly, in supporting / reinforcing pupil learning. Pupils also noted that they had enjoyed working with mentors, were grateful for the support they had been given, and valued the chance to build relationships with adults on a more personal level than is usual in the school setting. Indeed, HSBC as a corporation was perceived to have benefited from project involvement, albeit indirectly, through the experiences gained by their employees. As the Head of HSBC in the Community noted:

I think that the amount that our staff have got out of this over the years has been phenomenal and that, for us, is a very positive outcome of this. It's not just that people have done it, but how that has impacted some people, as an individual and also in their professional development. (End of project interview)

Certainly, many of the mentors commented that they felt they had gained both professionally and personally through the mentoring experience. The most commonly cited 
reason HSBC employees gave for volunteering to become a mentor was that they wanted to "help" young people and, in this way, there is some overlap with the philanthropic sentiments of the project sponsor. This was not always articulated very clearly, but there was an apparent desire among mentors to use a range of their experiences, interests and skills to inform, inspire, and encourage the young people involved in the project:

I'd like to be a(nother) positive adult influence in the young people's lives, teach them new skills that might help them improve their quality of life and widen their horizons to the world that is out there (Zoë, Year 4 mentor)

After their first attempt at mentoring during the physical activity weeks, a number of the mentors described the experience as having been "enjoyable”, “challenging” and “inspiring”. For some, the mentoring process had identified new personal skills and a desire to undertake subsequent work with young people:

(It's been) emotionally draining, physically demanding, VERY rewarding both in learning about leadership, and about myself, and about putting something back (Paul, Year 1/3 mentor)

In general I thought it was brilliant, I thoroughly enjoyed it, and I got a lot out of it from a personal point of view (Janet, Year 2 mentor)

However, it is also evident that there are a number of significant issues in need of further consideration in structured mentoring programmes of this nature. For example, many of the mentors (around $60 \%$ of all mentors involved throughout the life of the project) had little or no prior experience of working with young people (Armour \& Sandford, 2008). This led some mentors to hold strong preconceived notions about the behaviours, attitudes, and abilities of the young people whom they would be mentoring:

I thought they'd be more naughty, and they weren't. They were really nice kids...I suppose you stereotype don't you, you know inner city London school kids, from poor backgrounds, you'd think there'd be frightening scenes of... whatever (Iain, year 1/3 mentor). 
Indeed, there was some suggestion that the mentor training has exacerbated mentor concerns in this respect, with one mentor saying "they certainly made us aware of the worst case scenarios!” (Judith, Year 1 mentor). As such, some mentors were concerned that they would be unable to build positive relationships with, or provide effective support for, the young people in their groups: "I thought that there would be a really huge age gap and that I wouldn’t be able to relate to the kids at all” (Adrian, Year 1 mentor). However, mentors were then taken aback to find that they had a real impact on some of the young people:

I was surprised by what they wrote in the presentations, and the amount of impact we had on them. It was quite a shock to hear how emotional they were to us...I'm a role model! (Ali, Year 2 mentor)

As noted above, the positive perception by mentors was supported by some of the pupils. For example, Jenna (a year 1 participant) commented that "I really liked my mentor, she was funny and supportive and was there for us”; while Casey (a year 3 participant) noted that “my mentor helped me because some things I was doing she said I shouldn’t do because I would regret it later”. Nonetheless, lack of clarity about the mentor role, identified, in part, in the first project Logic Model, caused problems for all project participants. For example, after their first experience of mentoring on the Outward Bound activity week, mentors reported:

It's the frustration of not knowing what we were doing, where we were supposed to be and who was organising things (Val, Year 1/3 mentor)

No-one really knew what was expected of us (at the activity weeks), when we were supposed to be somewhere, where we were supposed to be, what we were supposed to be doing, and that was quite mentally draining (Judith, Year 1 mentor)

Similarly, teachers and instructors expressed some confusion concerning the role of mentors within the project, particularly in relation to the educational nature of their 
involvement. For example, one mentor recounted a conversation with an Outward Bound instructor:

I think it was quite confusing for the instructors, because the first question that my (instructor) said to me was 'so why are you here? What's your role? And you needn't think you're going to interfere with anything I'm going to do' (Diane, Year 2 mentor)

In addition, one teacher noted:

Although I realise that the HSBC guys were classed as mentors, they weren't necessarily mentoring per se. It was more like them being role models, visible role models who the kids could touch base with (Joel).

This reinforces the findings of other mentoring studies and shows the difficulty in establishing a clear and agreed definition of mentoring (e.g. Philip \& Hendry, 2000; Roberts, 2000). In particular, it was clear that despite undergoing mentor training, individuals had differing ideas about the mentor role, with some describing themselves as active "helpers" and "supporters”, and others simply as "neutral adults” or "additional aides”. Interestingly, when asked to describe what they felt the mentor role meant to them, very few of the HSBC volunteers identified themselves as 'educators' or saw themselves functioning in an educational role.

I think it's being encouraging, being an alternative person. You're not a teacher and you're not an instructor, so if they're not sure who to go to then you'll do almost, (you're) another option (Diane, Year 2 mentor)

I thought, well I'm not the teacher, I'm not the parent, I'm not the instructor, I'm there really as a neutral person...to support the young people or be someone they can talk to about whatever it might be (Janet, Year 2 mentor)

As was noted earlier, the process of Logic Model development undertaken in the early stages of the evaluation suggested that this lack of clarity might be a problem for the project and hinted at the resulting problem of role ambiguity for mentors. Consequently, in the first 
evaluation report to the project sponsors (Armour \& Sandford, 2004 p.76) the following recommendations were made: the role for mentors needs clearer definition; the assumptions underpinning mentors' notions of 'doing good things' for the young people requires further explication; and the parameters of the mentor role, and any personal communication between young people and mentors, needs further thought. It can be speculated, therefore, that had the evaluators been involved earlier in the project design phase, this issue could have been identified, discussed and, quite possibly, resolved before the project commenced. Indeed, although in subsequent activity weeks mentor roles became clearer thanks, in part, to the lessons learnt through the initial mentors' experiences and the provision of more detailed/sustained training, the question of clarifying the ways in which mentors could be more actively engaged in informal education processes during the activity sessions, and in subsequent follow-up activities in schools remained largely unanswered.

The importance of establishing sustained relationships between mentors and young people is supported in both the youth mentoring literature and in the physical education literature (e.g. Rhodes, 2004; Petitpas, Cornelius \& Van Raate, 2008). DuBois, Neville, Parra \& Pugh-Lilly (2002), for example, have noted that the regularity and frequency of contact between mentors and young people, and the longevity of this contact, are the key findings that emerge from the body of research on effective mentoring relationships. Moreover, Hellison, Martinek \& Walsh, (2008) have commented that "the strength of adult-youth relationships account for a significant portion of youth program success” (p.49). It is certainly clear from the data generated in this research that the most effective mentors were perceived (by pupils, teachers and mentors themselves) as being those who actively engaged with the young people and developed more than a transitory and superficial relationship. Indeed, in one example where a lasting relationship had been made between a mentor and pupil, this relationship was highlighted by the pupil's teacher as a contributory factor in the young 
person's sustained positive improvement ("I know he finds his mentor helpful and supportive”). Having said this, however, on the whole the mentors in this project found that there were few opportunities to develop ongoing relationships with the young people, and were aware that this limited their potential to have a sustained learning impact. Thus, while all parties seemed to recognise the importance and the potential benefits of sustained mentor contact with the young people, there was no clear plan in place to make this happen:

I think that it would be a great shame after the effort and the interest that the mentors have put into it, that there is nothing more...It's just how do we maintain that, you know, how do we physically do it. Whether it's by email or telephone or meetings, how do we keep in touch with these kids so that we don’t lose what we’ve already built (Melissa, Year 1 mentor)

It's actually an issue, what is our role of 'mentor' going forward. Is it just to be there on some of these activities, to be a helper or supporter? I think there is more to it than just being there as another aide to make sure that the activities happen... you've got to keep contact with the young people (Janet, Year 2 mentor)

These findings reinforce some existing research. Rhodes, Grossman \& Roffman, (2002), for example, have noted that mentor programmes located within or through schools are often limited in their impact, and highlight research by Astletine and colleagues (2000) which showed that the benefits of school-based mentoring programmes did generally not persist beyond the school (or project) year. The data from this project certainly offer some reasons for such findings; essentially the planning required for longer term involvement with pupils is extensive and there are numerous structural, contextual and ethical barriers to overcome. Indeed, it is worth noting that the ongoing mentor-pupil relationship mentioned in the above example was viewed very much as being independent of the project, due to the perceived difficulties and restrictions of communicating through 'official' channels. Certainly, it is clear that attempting to establish/maintain links between non-teacher adults who are not linked formally to the school, and young people (more so, groups of young 
people) requires careful coordination. In this project, however, it was unclear who could or should have taken responsibility for linking outsider adults to internal school processes. This can perhaps be seen to reflect something of the difficulty, identified in the informal education literature, regarding the link between formal and informal education. This will now be discussed in the following section and the implications for future programme development considered.

\section{Implications}

Many of the positive impact quotes from mentors, teachers and pupils resonate with the positive benefits claimed in the mentoring and informal education literatures, for example: non-teacher adults can positively influence young people's learning and development; mentors who are interested and enthusiastic are more likely to effect positive outcomes; and significant learning can occur outside of formal school structures and result from day-to-day interactions/experiences. What seems clear from this research is that the outdoor physical activity setting did provide an appropriate context for informal education. In particular, the activities undertaken allowed for the development of key life skills (e.g. teamwork, communication skills and problem solving) and the process of reflecting on experiences and achievements helped to reinforce learning and encourage a consideration of how those skills could transfer to other contexts. However, it is also evident that careful programme planning and mentor preparation/training are essential if all participants are to share a common framework of understanding prior to undertaking their mentor and informal educator roles if the potential of the process is to be maximised (Roberts, 2000; Rhodes, 2004). Certainly, within the HSBC/OB project, the ongoing development of the mentor training appeared to result in less confusion regarding the mentor role and a greater appreciation of the informal education process. As one year 4 mentor noted: 
we don't always realise it but we are actually educators in the most broadest sense...you inadvertently provide education because you're providing meaning to what they're doing (Mark, Year 4 Mentor)

This process of planning and preparation could help to address some of the concerns highlighted in this research, and mirrored elsewhere (e.g. Philip, Shucksmith \& King, 2004; DuBois et al., 2002), that mentors experience role ambiguity and have difficulty negotiating boundaries within mentoring relationships. Moreover, it is evident that mentors can benefit from having a clear understanding of the IE process so that in their relationships with young people, they maximise the potential learning opportunities. It is argued that this has wider implications for youth mentoring initiatives. As was noted earlier, IE is rarely curriculum driven, relying instead on the processes of everyday life to create environments for learning to take place (Smith, 2006). Through the use of shared activities and conversation, as identified by Richardson and Wolfe (2001), participants are able to reflect on their learning and development but it is also important to remember that IE is essentially purposeful. The findings of this evaluation research, however, would appear to suggest that while there were clear aspirations for the mentoring process to deliver learning outcomes, in practice it was a rather more 'accidental' than intentional process for the majority of the volunteers mentors.

This research also illustrates an internal tension in the IE literature that was noted earlier. On the one hand, it is argued that IE should remain on the margins of formal educational structures in order to retain its uniqueness and identity (Jeffs, 2001). Smith (2006) for example argues that where practitioners are drawn into the:

Centre of systems...they fall prey to the very things they need to be counteracting...and their role becomes centralised...diminishing the agency of learners (p. 24).

It could also be argued, however, that IE can only become more established and accepted if it finds ways of operating within recognised educational environments (Crossman, 2001). In this regard, it could be argued that the HSBC/OB project offered one such 
opportunity. The project was organised and structured around specific schools and with the involvement of teachers but, at the same time, the main project activities were located in a different educational setting (Outward Bound centres or other outdoor spaces) with additional learning support for pupils (mentors). Moreover, the mentors, in theory at least, were to have a sustained involvement with young people once they returned to the formal school setting. This can be seen to provide a potential means of bridging the gap between informal and formal education, in particular through facilitating the transfer and application of skills from informal to more formal learning contexts.

As has been illustrated, for mentoring to 'work' as intended in this project, there was a need for more thorough pre-planning, particularly in establishing open communication mechanisms between mentors and schools. There also needed to be a shared understanding of mentor and school staff roles, and some conceptual understanding of how these individuals would work together. In a study of mentor relationships between new and experienced physical education teachers, Patton et al. (2005) highlight some similar problems. They note the importance of a shared sense of community, commenting that:

Future studies could usefully explore how teachers, mentors and researchers who do not see themselves as belonging within a community experience a mentoring relationship (p.322).

In addition, Patton et al. (2005) point to the need to provide frequent opportunities for teachers and mentors to interact, and suggest that the sustainability of positive mentoring relationships needs further thought, as this is a key factor for success.

\section{Conclusion}

It is clear that youth mentoring is becoming increasingly fashionable, and that it has the potential to enhance informal education outcomes through youth physical activity programmes; however, questions remain about how best to optimise the opportunity. How 
can we ensure that mentors are not merely 'additional adults' passively supporting young people engaged in other activities, but are effective informal educators fostering learning within their groups and reinforcing the work of physical education professionals? This research points to a number of starting points for programme designers: establishing a defined mentor role; linking mentoring more closely with the practices of informal education; ensuring that mentors are keen and committed to the process; and ensuring there is detailed mentor preparation. Indeed, one of the mentors engaged in the HSBC/OB project has become fully committed to the youth mentoring process. He has, of his own volition, read additional material (on IE, the philosophy of education and mentoring), communicated with school staff, made frequent visits to schools, and organised follow-up activities for pupils. He has become increasingly convinced of the need for mentors to maintain contact with the young people ("it is all important") and he is keen to motivate other mentors to retain the momentum of the projects generated during the activity weeks. As a result, this mentor is very clear about his role in the project, grasping the balance between informal and formal learning:

Your role is really to encourage people and make them work as a little sort of unit together... and it is really to be there almost in the background. But sometimes you are not in the background you are at the front guiding people, so you are leading at some point and then you are following...it is completely dynamic; the role, it changes all the time (Nick, Year 3 mentor).

This mentor demonstrates what is possible when motivated individuals fully engage with the mentoring and informal education process and seek to work with and alongside other learning professionals. Researchers have noted the importance of having 'appropriate' individuals involved with the development and delivery of youth physical activity programmes, and have also highlighted the need for enthusiastic, effective and inspirational leadership (e.g., Petitpas et al., 2008; Sandford, Armour \& Duncombe, 2008). The above 
discussion would seem to suggest that, for mentors, the need to be informed and aware of the role they are expected to play, and the value of this role, is equally important.

Similarly, it could be argued that physical education teachers and youth sport coaches could gain from a greater awareness of the strengths and limitations of involving mentors in youth physical activity programmes, and about the potential benefits both informal educators and physical educators can gain from the articulation between their philosophies. In particular, physical education teachers need to be aware of the ways in which mentors can enrich the physical activity learning environment and can help them to deliver personal and social development through physical education. As Lawson (1995) has argued:

Just as a team of sports specialists 'wraps around' an elite athlete, so now must many of us learn how to work as an inter-professional team, which 'wraps around' the needs, problems, and aspirations of children, youth and families (p.416).

Elsewhere, one of the authors has argued that career-long continuing professional development for physical education teachers (PE-CPD) is lacking in challenge and variety and that it fails to support PE teachers in their aspirations for the learning outcomes of their physical education programs (Armour \& Yelling, 2004a,b). We would argue, therefore, that taken together, research such as that presented in this paper, the theoretical and practical constructs governing 'informal education', and the existing literature on young people's personal and social development through physical education, comprise challenging material that can usefully inform future developments within the field. 


\section{References}

Astletine, R.H., Dupre, M. \& Lamlein, P. (2000). Mentoring as a drug prevention strategy: an evaluation of Across. Ages Adolescent and Family Health, 1(1), 11-20.

Armour, K.M. \& Yelling, M.R. (2004a). Continuing professional development for experienced physical education teachers: Towards effective provision. Sport, Education and Society, 9(1), 95-114.

Armour, K.M. \& Yelling, M.R. (2004b). Professional development and professional learning: bridging the gap for experienced physical education teachers. European Physical Education Review, 10(1) , pp. 71-94.

Armour, K.M. \& Sandford, R.A. (2004). HSBC/Outward Bound project report (6 months). Loughborough University, UK: Institute of Youth Sport.

Armour, K.M. \& Sandford, R.A. (2008). HSBC/Outward Bound project report (Final Report). Loughborough University, UK: Institute of Youth Sport.

Bailey, R. (2008). Youth sport and social inclusion. In: N. Holt (Ed.), Positive Youth Development and Sport (pp.85-96). London: Routledge.

Bailey, R., Armour, K., Kirk, D., Jess, M., Pickup, I., \& Sandford, R. (2009). The educational benefits claimed for physical education and school sport: An academic review. Research Papers in Education, 24(1), 1-27.

Bennetts, C. (2003). Mentoring youth: Trend and tradition. British Journal of Guidance and Counselling, 31(1), 63-76.

Boud, D. (1985). Reflection: Turning experience into learning. London: Kogan Page.

Brew, J. M. (1946). Informal education: Adventures and reflections. London: Faber \& Faber.

Bruner, J. (1960). The process of education. Cambridge, Mass: Harvard University Press.

Bryman, A. (2006). Mixed methods research: Four volume set. London: Sage.

Burbules, N.C. (1993). Dialogue in teaching: Theory and practice. New York: Teachers College Press.

Burt, J.J. (1998). The Role of Kinesiology in Elevating Modern Society. Quest, 50, 80-95.

Charmaz, K. (2000). Grounded theory: Objectivist \& constructionist methods. In N.K Denzin \& Y.S. Lincoln (Eds.), Handbook of qualitative research 2nd Edition (pp. 509-536). London: Sage.

Clark, A. \& Moss, P. (2001). Listening to young children: The mosaic approach. London: National Children’s Bureau/Joseph Rowntree Foundation. 
Colley, H. (2003a). Mentoring for social inclusion: A critical approach to nurturing mentor relationships. London: Routledge Falmer.

Colley, H. (2003b). Engagement mentoring for socially excluded youth: Problematising an 'holistic' approach to creating employability through the transformation of habitus. British Journal of Guidance and Counselling, 31(1), 77-99.

Colley, H., Hodkinson, P., \& Malcolm, J. (2002). Non-formal learning: Mapping the conceptual terrain. A Consultation Report. Leeds: University of Leeds Lifelong Learning Institute.

Connell, J.P., \& Kubisch, A.C. (1998). Applying a theory of change approach to the evaluation of comprehensive community initiatives: Progress, prospects, problems. In K. Fulbright-Anderson, A.C. Kubisch, \& J.P. Connell (Eds.), New approaches to evaluating community initiatives (pp.15-44). Washington DC: Aspen Institute.

Crabbe, T. (2006). Going the distance: impact, journeys and distance travelled (third interim national Positive Futures case study research report). Retrieved 18 July, 2007, from http://www.positivefuturesresearch.org.uk.

Crossman, D.J. (2001). Informal educators go back to school. London: YMCA George Williams College.

Danish, S. J. (2002). Teaching life skills through sport. In M. Gatz, M. A. Messner \& S. J. Ball-Rokeach (Eds.), Paradoxes of youth and sport (pp. 49-59). Albany, NY: State University of New York Press.

Davies, B. (2005). Threatening youth revisited: youth policies under New Labour. Retrieved July 18, 2006, from

www.infed.org/archives/bernard_davies/revisiting_threatening_youth.htm

Dewey, J. (1961). Democracy and education: An introduction to the philosophy of education. New York: Macmillan.

Dewey, J. (1933). How we think. New York: D.C. Heath.

Department for Education and Employment (DfEE) (2000). How to evaluate education initiatives: A guide for schools. Nottingham, UK: DfEE.

Department for Education \& Skills (DfES) (Department for Education and Skills) (2005) Learning Behaviour: The report of the practitioner's group on school, behaviour and discipline. Nottingham, UK: DfES.

Doyle, M.E. (2001). On being an educator. In, L.D. Richardson \& M. Wolfe (Eds), Principles and practice of informal education: Learning through life (pp. 4-16). London: Routledge Falmer. 
DuBois, D.L., Neville, H.A., Parra, G.R. \& Pugh-Lilly, A.O. (2002). Testing a new model of mentoring. In J.E. Rhodes (Ed.), A critical view of youth mentoring: New directions for youth development, No. 93 Spring 2002 (pp. 21-57. San Francisco, CA: JosseyBass.

DuBois, D.L. \& Karcher, M.J. (2005). Youth mentoring: theory, research and practice. In D.L. DuBois \& M.J. Karcher (Eds.), Handbook of youth mentoring (pp.2-11). Thousand Oaks, CA: Sage Publications.

Fraser-Thomas, J.L., Côté, J. \& Deakin, J. (2005). Youth sport programs: an avenue to foster positive youth development. Physical Education and Sport Pedagogy, 10(1), 19-40.

Freire, P. (1972). Pedagogy of the oppressed. Harmondsworth: Penguin.

Garvey, B. \& Alred, G. (2000). Educating mentors. Mentoring and Tutoring, 8 (2) 114-126.

Glaser, B. G., \& Strauss, A.L. (1967). The discovery of grounded theory: Strategies for qualitative research. New York: Aldine de Gruyter.

Granger, R.C. (1998). Establishing causality in comprehensive community initiatives. In K. Fulbright-Anderson, A.C. Kubisch \& J.P. Connell (Eds.), New approaches to evaluating community initiatives: Theory, measurement and analysis, vol 2 pp. 22146 (Washington DC, The Aspen Institute).

Guskey, T.R. (2005-6). A conversation with Thomas Guskey. The evaluation exchange. X1(4), 12-15

Harper, D. (2002). Talking about pictures: a case for photo elicitation, Visual Studies, 17(1), $13-26$.

Harry, B., Sturges, K.M., \& Klingner, J.K. (2005). Mapping the process: An exemplar of process and challenge in grounded theory analysis. Educational Researcher, 34(2), 313.

Hellison, D. (1995). Teaching responsibility through physical activity. Champaign, IL: Human Kinetics.

Hellison, D., Martinek, T. \& Walsh, D. (2008). Sport and responsible leadership among youth. In N.L.Holt (Ed.), Positive youth development through sport (pp.49-60). London: Routledge.

Holt, N. (Ed). (2008). Positive youth development through sport. London: Routledge.

Holt, N.L. \& Sehn, Z.L. (2008). Processes associated with positive youth development and participation in competitive youth sport. In N.L.Holt (Ed.), Positive youth development through sport (pp.24-33). London: Routledge. 
House of Commons: Education and Skills Committee. (2005). Education outside the classroom: Second report of session 2004-05. London: DfES.

Jarvis, P. (1994). Learning, ICE301 Lifelong learning, unit, 1(1). London: YMCA George Williams College.

Jeffs, T., \& Smith, M. (1999). Informal education: conversation, democracy and learning (2nd Edition). Ticknel: Education Now.

Jeffs, T. (2001). First lessons: Historical perspectives on informal education. In, L.D. Richardson \& M. Wolfe (Eds.), Principles and practice of informal education: Learning through life (pp. 34-49). London: Routledge Falmer.

Kendall, S. \& Kinder, K. (2005). Reclaiming those disengaged from education and learning: a European perspective. Slough: National Foundation for Educational Resarch.

Kellogg Foundation (2001). Using logic models to bring together planning, evaluation and action: Logic model development guide. Michigan: W.K. Kellogg Foundation.

Larson, A., \& Silverman, S.J. (2005). Rationales and practices used by caring physical education teachers. Sport, Education \& Society, 10(2), 175-194.

Lave, J, \& Wenger, E. (1991). Situated learning: Legitimate peripheral participation. Cambridge: University of Cambridge Press.

Lawson, H.A. (1995). International changes and challenges: Their import for new models for practice, Quest, 47, 411-426.

Lawson, H.A. (1999). Education for social responsibility: preconditions in retrospect and in prospect, Quest, 51, 116-149.

Long, J., \& Sanderson, I. (2001). The social benefits of sport: Where's the proof?. In C. Gratton \& I. P. Henry (Eds.), Sport in the city: The role of sport in economic and social regeneration (pp. 187-203). London: Routledge.

Long, J., Welch, M., Bramham, P., Butterfield, J., Hylton, K., \& Lloyd, E. (2002). Count me in: The dimensions of social inclusion through culture, media \& sport. Leeds, UK: Leeds Metropolitan University.

Martinek, T. J., \& Hellison, D. R. (1997). Fostering resiliency in underserved youth through physical activity, Quest, 49(1), 34-49.

McGivney, V. (1999). Informal learning in the community: A trigger for change and development. Leicester: NIACE.

Merton, B., \& Parrott, A. (1999). Only connect: Successful practice in educational work with disaffected young adults. Leicester: NIACE. 
Miller, S. C., Bredemeier, B. J. L., \& Shields, D. L. L. (1997). Sociomoral education through physical education with at-risk children. Quest, 49, 114-129.

Oliver, K. L. \& Lalik, R. (2001). The body as curriculum: Learning with adolescent girls, Journal of Curriculum Studies, 33 (3), 303-333.

Outward Bound (2009). Outward Bound: History. Retrieved June 22, 2009, from http://www.outwardbound.org/index.cfm/do/ind.about_history

Parker, M. \& Stiehl, J (2005). Personal and social responsibility. In D. Tannehill, \& J. Lund, (Eds.). Standards based curriculum development. Boston, MA: Jones and Barlett.

Patton, K., Griffin, L.L., Sheehy, D., Arnold, R., Gallo, A.M., Pagnano, K., Dodds, P., Henniger, M., \& James, A. (2005). Navigating the mentoring process in a researchbased teacher development project. Journal of Teaching in Physical Education, 24, 302-325.

Patton, M.Q. (2002). Qualitative research and evaluation methods. Thousand Oaks, CA: Sage Publications.

Petitpas, A. Cornelius, A. \& Van Raalte, J. (2008). Youth development through sport. In N.Holt (Ed.), Positive youth development and sport (pp.61-70). London: Routledge.

Philip, K., \& Hendry, L.B. (2000). Making sense of mentoring or mentoring making sense? Reflections on the mentoring process by adult mentors with young people. Journal of Community \& Applied Social Psychology, 10, 211-223.

Philip, K. (2003). Youth mentoring: The American dream comes to the UK. British Journal of Guidance and Counselling, 31(1), 101-112.

Philip, K., Shucksmith, J. \& King, C. (2004). Sharing a laugh? A qualitative study of mentoring interventions with young people. York, UK: Joseph Rowntree Foundation.

Pitter, R., \& Andrews, D. L. (1997). Serving America’s underserved youth: Reflections on sport and recreation in an emerging social problems industry, Quest, 49(1), 85-99.

Punch, S. (2002). Research with children: The same or different from research with adults. Childhood: A Global Journal of Child Research, 9(3), 321-341.

Reid, K. (2002). Mentoring with disaffected pupils. Mentoring and Tutoring, 10(2), 153-169.

Rhodes, J. (2001). Youth mentoring in perspective: The center summer. Retrieved March 14, 2006, from http://www.infed.org/learningmentors/youth_mentoring_in_perspective.htm

Rhodes, J.E., Grossman, J.B. \& Roffman, J. (2002). The rhetoric and reality of youth mentoring. In J.E. Rhodes (Ed.), A critical view of youth mentoring, New Directions 
for Youth Development, No. 93 Spring 2002, (pp. 9-20). San Francisco, CA: JosseyBass.

Rhodes, J.E. (2004). Stand by me: The risks and rewards of mentoring today's youth. Cambridge, MA: Harvard University Press.

Richardson, L.D., \& Wolfe, M. (2001). The principles and practice of informal education: Learning through life. London: Routledge Falmer.

Roberts, A. (2000). Mentoring revisited: A phenomenological reading of the literature. Mentoring \& Tutoring, 8(2), 145-170.

Rogers, A. (2004). Looking again at non-formal and informal education: Towards a new paradigm. Retrieved June 2006 from http://www.infed.org/biblio/non_formal_paradigm.htm

Sandford, R.A., Armour, K.M. \& Warmington, P.C. (2006). Re-engaging disaffected youth through physical activity programmes. British Educational Research Journal, 32(2), 251-271.

Sandford, R.A., Armour, K.M. and Duncombe, R. (2008). Physical activity and personal/social development for disaffected youth in the UK: In search of evidence. In N. Holt (Ed.), Positive youth development and sport (pp.97-109). London: Routledge.

Sandford, R.A., Duncombe, R. \& Armour, K.M. (2008). The role of physical activity/sport in tackling youth disaffection and anti-social behaviour. Educational Review, 60(4), 419435.

Schön, D. (1983). The reflective practitioner: How professionals think in action. London: Temple Smith.

Shiner, M., Newburn, T., Young, T., \& Groben, S. (2004). Mentoring disaffected young people: An evaluation of mentoring plus. York: Joseph Rowntree Foundation.

Smith, M.K. (2006). Beyond the curriculum: Fostering associational life in schools. In Z. Bekerman, N. Burbules \& D Silberman-Keller (Eds.), Learning in places: The informal education reader. New York: Peter Lang.

Smink, J. (2000). Foreword. In R. Klein, Defying disaffection: how schools are winning the hearts and minds of reluctant students (p. ix). Stoke on Trent, UK: Trentham Books.

Steer, R. (2000). A background to youth disaffection: A review of literature and evaluation findings from work with young people. London: Community Development Foundation. 
Strauss, A. L., \& Corbin, J. (1998). Basics of qualitative research: Techniques and procedures for developing grounded theory (2nd edition). Thousand Oaks, CA: Sage Publications.

Theokas, C., Danish, S., Hodge, K., Heke, I. and Forneris, T. (2006). Enhancing life skills through sport for children and youth. In N. Holt (Ed.), Positive youth development through sport (pp. 71-81). London: Routledge.

Webb, R., \& Vulliamy, G. (2004). A multi-agency approach to reducing disaffection and exclusions from school. London: DfES.

Weiss, C. H. (1995). Nothing as practical as good theory: exploring theory-based evaluation for comprehensive community initiatives for children and families. In J. Connell, A. Kubisch, L. Schorr \& C. Weiss (Eds.), New approaches to evaluating community initiatives: concepts, methods, and contexts (pp.65-92). Washington DC: Aspen Institute.

Werner, E.E. (1995). Resilience in development. Current Directions in Psychological Science, 4, 81-85. 


\section{Endnotes}

The sponsors of the HSBC/Outward Bound project are 'HSBC in the Community', a sub-group of HSBC's corporate social responsibility arm that has responsibility for promoting positive relationships with the local community. HSBC itself is one of the world's biggest banks, its initials standing for the Hong Kong and Shanghai Banking Corporation from which it was founded.

2 The Outward Bound Trust is a global educational charity that has a long history (over 65 years) of using outdoor experiences and challenges to facilitate young people’s development.

3 Although the project itself was five years in length, the evaluation of impact covered the first four years only. This was to ensure that detailed analysis could be undertaken on the data generated through cohorts 1 to 4 , and that the progress of participating pupils could be followed for at least 12 months.

$4 \quad$ An extended school is one that provides a range of activities and services often beyond the school day, to help meet the needs of its pupils, their families and the wider community.

5 The Excellence in Cities programme came into place in 1999, and is designed to raise the aspirations and achievements of pupils in schools in disadvantaged areas. Part of the initiative includes employing learning mentors in selected schools and learning support units. 


\begin{tabular}{|c|c|c|c|c|c|c|}
\hline \multicolumn{4}{|c|}{$\begin{array}{l}\text { YOUR PLANNED WORK } \\
\text { (i.e. what you are planning to do) }\end{array}$} & \multicolumn{3}{|c|}{$\begin{array}{l}\text { YOUR INTENDED RESULTS } \\
\text { (i.e. what you are expecting to happen) }\end{array}$} \\
\hline \multicolumn{2}{|c|}{$\begin{array}{l}\text { RESOURCES/INPUT } \\
\text { i.e. elements/factors influencing your ability to do } \\
\text { work (positive or negative) }\end{array}$} & \multicolumn{2}{|c|}{$\begin{array}{l}\text { ACTIVITIES } \\
\text { i.e. what you then do with your resources }\end{array}$} & $\begin{array}{l}\text { OUTPUTS } \\
\text { i.e. the direct product } \\
\text { of your activities }\end{array}$ & $\begin{array}{l}\text { OUTCOMES } \\
\text { i.e. the changes to } \\
\text { participants' behaviour } \\
\text { (as a result of the } \\
\text { programme) }\end{array}$ & $\begin{array}{l}\text { IMPACT } \\
\text { i.e. the fundamental } \\
\text { changes in } \\
\text { organisations, } \\
\text { systems, } \\
\text { communities etc. as } \\
\text { a result of the } \\
\text { programme }\end{array}$ \\
\hline $\begin{array}{l}\text { Finances } \\
\text { Inter-personal networks }\end{array}$ & $\begin{array}{l}\text { HSBC funding } \\
\text { HSBC-OB relations } \\
\text { HSBC-school relations }\end{array}$ & \multirow{3}{*}{$\begin{array}{l}\text { Activities: } \\
\text { Book facilities } \\
\text { Arrange evaluation } \\
\text { Arrange steering group } \\
\text { meetings } \\
\text { Select schools } \\
\text { Select young people } \\
\text { Launch/Closure days } \\
\text { OB courses } \\
\text { Weekend course event } \\
\text { Classic course event } \\
\text { Follow-up activities }\end{array}$} & \multirow{3}{*}{$\begin{array}{l}\text { Led by: } \\
\text { OB } \\
\text { HSBC } \\
\text { HSBC } \\
\text { HSBC } \\
\text { Teachers } \\
\text { OB } \\
\text { OB } \\
\text { OB } \\
\text { OB } \\
\text { "To involve } \\
\text { mentors \& } \\
\text { teachers” [not } \\
\text { clear who takes } \\
\text { the lead here] }\end{array}$} & \multirow{3}{*}{$\begin{array}{l}\text { Programmes developed } \\
\text { Programmes/events run } \\
\text { launch day } \\
\text { Weekend course } \\
\text { Classic course } \\
\text { Follow-up activities }\end{array}$} & \multirow{3}{*}{$\begin{array}{l}\text { Young people are re- } \\
\text { engaged } \\
\text { Decreased disaffected } \\
\text { behaviour } \\
\text { Increased community } \\
\text { involvement } \\
\text { Young people as role } \\
\text { models within schools } \\
\text { [different people in the } \\
\text { partnership may have } \\
\text { different ideas here] } \\
\text { Also changes for: } \\
\text { HSBC, OB, Teachers, } \\
\text { Mentors etc. }\end{array}$} & \multirow{3}{*}{$\begin{array}{l}\text { Young people as } \\
\text { role models in the } \\
\text { community } \\
\text { Increased academic } \\
\text { achievement } \\
\text { Mentor relations } \\
\text { with schools } \\
\text { HSBC community } \\
\text { relations } \\
\text { OB corporate } \\
\text { relation }\end{array}$} \\
\hline People & $\begin{array}{l}\text { HSBC link } \\
\text { Out. Bound Link } \\
\text { Instructors (Inst) } \\
\text { School staff (Staff) } \\
\text { Mentors (Ment) }\end{array}$ & & & & & \\
\hline $\begin{array}{l}\text { Facilities } \\
\text { Equipment }\end{array}$ & $\begin{array}{l}\text { OB Centres } \\
\text { Schools } \\
\text { HSBC HQ }\end{array}$ & & & & & \\
\hline
\end{tabular}

Fig. 1 Basic Logic Model for the HSBC/Outward Bound project 


\begin{tabular}{|c|c|c|c|c|c|c|}
\hline Process & Raw data & Initial review of data & Coding / Memo writing & $\begin{array}{c}\text { Identifying points of } \\
\text { commonality }\end{array}$ & $\begin{array}{c}\text { Generation of } \\
\text { themes }\end{array}$ & $\begin{array}{c}\text { Linking back to data } \\
\text { generation }\end{array}$ \\
\hline Explanation & 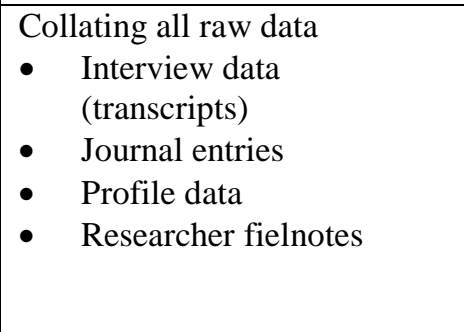 & $\begin{array}{l}\text { Scan through the data } \\
\text { and highlight points of } \\
\text { immediate interest } \\
\text { (considering, for } \\
\text { example, perceived } \\
\text { relevance to the research } \\
\text { questions, or project } \\
\text { aims/objectives }\end{array}$ & $\begin{array}{l}\text { Review the highlighted } \\
\text { data and begin to } \\
\text { identify categories or } \\
\text { codes by picking out key } \\
\text { words/phrases. } \\
\text { Alongside, make notes } \\
\text { (memos) to explain the } \\
\text { identification of codes. }\end{array}$ & $\begin{array}{l}\text { Review the codes (and } \\
\text { associated memos) and } \\
\text { begin to make links } \\
\text { between them. Also } \\
\text { identify links between } \\
\text { the data and literature } \\
\text { and different cohorts of } \\
\text { data. }\end{array}$ & $\begin{array}{l}\text { Group the codes / } \\
\text { categories into } \\
\text { clusters (themes) } \\
\text { according to points } \\
\text { of commonality. }\end{array}$ & $\begin{array}{l}\text { Identifying } \\
\text { questions/issues to } \\
\text { explore further in } \\
\text { subsequent interviews } \\
\text { or points to consider } \\
\text { in relation to project } \\
\text { development. }\end{array}$ \\
\hline Illustration & $\begin{array}{l}\text { (Mentor 1) I think actually } \\
\text { that after we had had that } \\
\text { meeting everyone was more } \\
\text { confused about what the role } \\
\text { of a mentor was than before } \\
\text { hand. And for me personally, I } \\
\text { still struggled with what you } \\
\text { as a mentor were supposed to } \\
\text { do, because I was on the } \\
\text { second week and everyone's } \\
\text { experiences with their group } \\
\text { was different } \\
\text { (Mentor 2) We found that we } \\
\text { all had different roles within } \\
\text { our groups, and that depended } \\
\text { upon the instructor and also } \\
\text { the young people in your } \\
\text { group...because I know that } \\
\text { Sean was more standing back, } \\
\text { whereas I was more of a link } \\
\text { between the young people and } \\
\text { the instructor. }\end{array}$ & $\begin{array}{l}\text { After... that meeting } \\
\text { everyone was more } \\
\text { confused about the role } \\
\text { of a mentor... } \\
\text { still struggled with what } \\
\text { you as a mentor were } \\
\text { supposed to do... } \\
\text { everyone's experiences } \\
\text { with their group was } \\
\text { different... } \\
\text { we all had different roles } \\
\text { within our groups, and } \\
\text { that depended upon the } \\
\text { instructor and the young } \\
\text { people ... } \\
\text { I know that Sean was } \\
\text { more standing back, } \\
\text { whereas I was more of a } \\
\text { link between the young } \\
\text { people and the } \\
\text { instructor. }\end{array}$ & $\begin{array}{l}\text { Differing opinions } \\
\text { regarding mentor role } \\
\text { e.g. "more confused } \\
\text { about the role of a } \\
\text { mentor"; "all had } \\
\text { different roles". } \\
\text { [Memo: highlights } \\
\text { various views regarding } \\
\text { mentor role and mentor } \\
\text { confusion. Interesting } \\
\text { that the meeting with } \\
\text { year } 1 \text { mentors was felt } \\
\text { to exacerbate this]. } \\
\text { Levels of engagement } \\
\text { e.g. "I know that Sean } \\
\text { was more standing back, } \\
\text { whereas I was more of a } \\
\text { link between the young } \\
\text { people and the } \\
\text { instructor" } \\
\text { [Memo: Active/Passive } \\
\text { variation. Reflects } \\
\text { confusion over role? Or } \\
\text { linked to context?] }\end{array}$ & $\begin{array}{l}\text { Differing opinions } \\
\text { regarding the mentor role } \\
\text { and level of engagement } \\
\text { required with the young } \\
\text { people. Can be seen to } \\
\text { reflect a generic } \\
\text { confusion regarding the } \\
\text { precise role of a mentor } \\
\text { in this project } \\
\text { ("struggled with what } \\
\text { you as a mentor were } \\
\text { supposed to do"). } \\
\text { - Year 1 mentors also } \\
\text { highlighted this } \\
\text { confusion (e.g. "no- } \\
\text { one actually really } \\
\text { knew what was } \\
\text { expected of us") } \\
\text { Also some teacher } \\
\text { data to support this } \\
\text { (see School E } \\
\text { feedback, year 1) } \\
\text { Links to literature } \\
\text { here (e.g. Roberts, } \\
\text { 2000; Bennetts, } \\
\text { 2003) }\end{array}$ & $\begin{array}{l}\text { Key Theme: } \\
\text { Confusion over } \\
\text { mentor role } \\
\text { ("I still struggled } \\
\text { with what you as a } \\
\text { mentor were } \\
\text { supposed to do, } \\
\text { because... } \\
\text { everyone's } \\
\text { experiences with } \\
\text { their group was } \\
\text { different"). }\end{array}$ & $\begin{array}{l}\text { What is the } \\
\text { particular role } \\
\text { expected of } \\
\text { mentors in the } \\
\text { HSBC/Outward } \\
\text { Bound project? } \\
\text { [to clarify with } \\
\text { project sponsors] } \\
\text { (How) can } \\
\text { mentor training } \\
\text { be adapted or } \\
\text { developed to help } \\
\text { address the } \\
\text { problem of role } \\
\text { confusion? } \\
\text { Should we expect } \\
\text { to have a clear / } \\
\text { agreed definition } \\
\text { of mentoring, or } \\
\text { should it be down } \\
\text { to an individual } \\
\text { to find the right } \\
\text { role for the } \\
\text { context? }\end{array}$ \\
\hline
\end{tabular}

Fig. 2 Illustrative example of the data analysis process 